\title{
Representasi Betara Kala dalam Pertunjukan Teater Kontemporer Kalamanungsa
}

\author{
INDRA SUHERJANTO* \\ Jurusan Sastra Indonesia, Fakultas Bahasa dan Seni, Universitas Negeri Malang
}

\begin{abstract}
Representation of Batara Kala in Contemporar Theater of Kalamanungsa. This Kalamanungsa theater tells humanitarian issues, the journey of human life, human beings who have characters that need to find a way out for the better life. Starting from the myth Betara Kala that was born not intentionally emerges a wide range of results. Kalamanungsa will show something different. Existence Betara Kala, Kala Betara existence presented, and the myth of the birth of stalling and Betara Kala is an inspiring creation performance theater Kalamanungsa. Kalamanungsa raised the issue of modern society life with invented characters, with burdened by the dialogues that contain philosophy, poetry, with strong musical aspect. Kalamanungsa is showed with a modern theatrical approach, by presenting the symbols to express meaning and emotion, using multimedia, projector/LCD, with music that is processed on a computer elaborated with a variety of traditional and modern musical instruments as the stage spectacle which is intentionally presented to give specific meaning. Theater performance Kalamanungsa tries to explain all elements of art in a show, like music art, dance art, lighting and other art media with hope that Kalamanungsa will attend as a show of modern theater.
\end{abstract}

Key words: Batara Kala, Kalamanungsa, Teater kontemporer

\section{Pendahuluan}

Pertunjukan teater Indonesia tidak asing dengan kontribusi mitos-mitos cerita lisan. Banyak pertunjukan teater modern berawal dari cerita rakyat atau tradisi lisan. Kisah Mahabharata dan Ramayana banyak dijadikan ide penulisan naskah drama dan pertunjukan teater, Pertunjukan teater La Galigo misalnya dibuat berdasarkan cerita lisan tentang La Galigo dari budaya Bugis, yang telah dipentaskan di beberapa negara (Sarumpaet, 2004: 86). Bukan hal yang aneh jika nilai-nilai tradisi atau mitologi wayang banyak berpengaruh terhadap penulisan karya sastra dan penciptaan karya seni teater Indonesia. Mitologi sebagai kristalisasi konsep-konsep, nilainilai, dan norma-norma yang menjiwai sikap hidup masyarakat yang selama ini menyebabkan komunikasi antar anggota masyarakat menjadi efisien.

Sebagai sumber nilai-nilai tradisi dan norma, fungsi pewayangan masih akan lama hidup dalam masyarakat khususnya di Jawa. Sebagai bentuk hiburan (entertainment) pewayangan harus menghadapi persaingan yang berat oleh tampilnya bentuk-bentuk hiburan baru dan juga oleh berubahnya sifat-sifat kehidupan masyarakat karena peralihan ke taraf yang lebih modern. (Hasan, 1993: 46).

Ketika tradisi lisan menjadi sumber, maka identitas cerita lisan atau tradisi lisan tidak lagi berbicara hanya di sekitar pemiliknya, tetapi juga bersinggungan dengan nilai-nilai budaya dari penikmatnya yang lain. Hal ini sejalan dengan konsep dinamika sosial, bahwa semua proses pergolakan menuju perubahan sosial dengan daya gerak sejarah yang pada setiap tahap mendorong ke arah tercapainya keseimbangan baru yang setinggi dengan kondisi dan keadaan zaman. Menurut Comte dalam K.J. Veegar (1990: 25) setiap perubahan di bidang politik, hukum, tata pemerintahan, kesenian, agama, ilmu pengetahuan, dan filsafat langsung berkaitan dengan hukum akal budi. Tiap tahap baru dalam cara manusia berfikir menghasilkan bentuk masyarakat baru pula. Perilaku manusia tidak hanya berasal dari akal budi saja, melainkan juga hati: perasaan dan kemauan.

*Alamat Korespondensi: Universitas Negeri Malang, Jln. Semarang No. 5 Malang - 65145, Tlp. 0341-567475 e-mail: info@sastra. um.ac.id 
Tradisi sering diterjemahkan sebagai pewarisan, norma-norma, dan adat-istiadat yang perlu dipertahankan. Sikap demikian sering dipertentangkan dengan pengertian modern atau perubahan. Bagi yang tunduk pada nilai-nilai dan konsep tradisi, mereka menganggap tradisi sebagai sesuatu yang agung dan klasik serta memiliki aspek-aspek spiritual yang tidak boleh disentuh karena dianggap sebagai sesuatu yang keramat atau sakral. Pemikiran yang tunduk pada konsep tradisi seperti pernyataan di atas bertentangan dengan pemahaman para intelektual sosial. Myron Weiner (1994: ii) mengutip pendapat sejumlah intelektual sosial yang menyatakan bahwa,

“... sejumlah sarjana sosial menyatakan bahwa yang dikatakan tradisi adalah menunjuk pada kepercayaan dan kebiasaan-kebiasaan dari masa lampau; kalau kita mengadakan penafsiran kembali terhadap masa lalu, maka tradisi kita akan berubah".

Intelektual modernisme menafsirkan sesuatu yang memiliki konsep tradisi sebagai sesuatu yang sudah tidak memadai lagi karena kebutuhan sosial menghendaki suatu bentuk struktur, pola, atau sistem yang baru. Pemahaman tersebut menimbulkan praduga seakan-akan konsep modernisasi menentang konsep tradisi; termasuk dalam bidang seni pertunjukan teater.

Disadari ataupun tidak pergerakan tatanan kehidupan telah menciptakan perubahan menuju masyarakat yang modern. Percepatan pergerakan tatanan ini justru menciptakan masyarakat modern yang padaumumnyahanyapermukaan, bungkusnya saja, secara fisik tampilan merasa modern, berteknologi dan mengikuti perkembangan zaman namun secara psikis dan perilaku masih berkutat pada mitos-mitos. Masyarakat modern atau merasa modern dengan segala problematikanya akan selalu berpikir bahwa manusia layaknya mengolah habis suratan takdirnya serta mengubah nasibnya dan seolah-olah sebagai keharusan agar memperoleh kehidupan yang lebih baik. Berbagai macam cara digunakan sebagai jalan untuk menyelesaikan masalah. Ini fakta masyarakat kita dan hal ini merupakan sumber awal proses kreatif pertunjukan teater Kalamanungsa ini.

Pergerakan tatanan kehidupan seperti tersebut di atas cukup berpengaruh pada dunia perteateran di Indonesia. Teater modern Indonesia, hingga saat ini juga masih belum betul-betul menjadi milik masyarakat. Teater Indonesia masih merupakan fenomena kota besar dan hanya diterima oleh sebagian kecil penonton (Saini, 2000: 46). Sebagian kecil penonton itu pada umumnya kelompok masyarakat intelektual. Teater modern Indonesia masih berkembang dengan segala pasang surut dan pergolakan-pergolakan pemikirannya, masih belum mempunyai dunia yang mapan.

Dengan demikian para seniman harus bergerak cepat dan leluasa agar seni yang digelutinya dapat diterima oleh masyarakat, terlebih dengan meluasnya sistem pengetahuan dan teknologi dan meningkatnya hubungan komunikasi di segala bidang. Salah satu upayanya adalah dengan menampilkan seni pertunjukan (dalam hal ini teater) melalui dan memanfaatkan teknologi baik dalam peristiwa pertunjukannya maupun penyebaran informasinya. Alvin Tovler (1970: 484) menyatakan bahwa seni pertunjukan akan bisa hidup subur apabila masyarakat telah benarbenar menjadi konsumen atau penikmat budaya.

Di era sekarang, di saat dunia (negara) kita terbawa arus barang mewah dan teknologi modern, berbagai ilmu seperti ilmu-ilmu eksakta atau ilmu pasti yang dikhawatirkan menggusur dunia rekaan dan imajinasi berkembang dengan pesat tidaklah mengendurkan semangat berteater. Teater tetap dibuat dan diciptakan. Perkembangan teknologi modern, seperti: komputer, musik digital, proyektor/ LCD dan sebagainya justru seharusnya membantu tumbuhkembangnya penciptaan teater maupun minat masyarakat untuk berteater.

Penggunaan teknologi tersebut merupakan bagian dari usaha untuk mencari idiom dan bahasa ekspresi pertunjukan yang baru dan segar. Cara berekspresi baru untuk mengutarakan sebuah kebenaran yang terus tumbuh diperlukan bahasa yang baru, untuk mengucapkan kenyataankenyataan yang terus menerus berkembang. Apa pun bentuknya, apa pun namanya, yang oleh Putu Wijaya (1993: 1) disebut bahasa kontemporer.

Konsep dasar kontemporer adalah pembebasan dari kontrak-kontrak penilaian yang sudah kedaluwarsa, tetapi juga bisa berbalik menjadi dehumanisasi, akulturasi dan dekadensi. Seni kontemporer sebagai bagian dari pelafalan konsep kontemporer selalu membebaskan diri dari kemacetan pada satu nilai yang semula disangka 
sebagai sumber segalanya, padahal segala sesuatu itu ternyata sudah bergeser dan menjungkir-balik segala-galanya.

Pertunjukan seni Indonesia kontemporer adalah anak dari konsep kontemporer Pertunjukan kontemporer, bukan hanya tontonan yang diciptakan dan dilakukan oleh manusia masa kini, tetapi juga pertunjukan yang mencerminkan pembebasan. Perbedaan tidak lagi sesederhana hitam putih, kiri dan kanan, buruk lawan baik, atau tradisi lawan kontemporer saja, tetapi merupakan kehadiran tak terhingga nuansa yang memerlukan cara berpikir baru (kontemporer) untuk menguasainya. Nilai-nilai bertumpukan, tumpang-tindih, nyaris membingungkan, dalam satu susunan harmoni baru yang tak terbayangkan sebelumnya. Wujudnya bisa berupa pertunjukan eksperimental, yang merupakan usaha untuk pencarian-pencarian idiom dan bahasa pengucapan yang baru/segar. Dapat pula berwujud pertunjukan konvensional, yang memanfaatkan semua konvensi pertunjukan yang sudah diterima oleh masyarakat, namun memberikan nuansa yang baru atau lain yang lebih segar dari sebelumnya.

Menggugah Betara Kala lewat pertunjukan teater Kalamanungsa ini diharapkan dapat dimanfaatkan sebagai problem solving yang berkembang di masyarakat dewasa ini sekaligus sebagai ekspresi komunikasi, sebagai sarana pemahaman seni budaya, baik tradisional maupun modern, dan sebagai media pendidikan dan pembelajaran terhadap nilai-nilai budaya di Indonesia. Harapan yang ideal adalah terciptanya suatu keseimbangan alam dan kehidupan di muka bumi.

\section{Metode Transmisi Patrice Pavice}

Pertunjukan Teater Kalamanungsa dalam proses penciptaannya menggunakan metode yang diteorikan oleh Patrice Pavis (1992: 185). Pavis membuat satu bagan alur bagaimana elemenelemen teatrikal pertunjukan teater memindah pesan budaya sumber menuju ke budaya target. Teater memiliki peralatan khas bagi pemindahan suatu budaya sumber kepada budaya target, yaitu melalui konteks teater. Intertekstualitas di dalam pertunjukan teater merupakan praktik pembacaan teatrikal. Pavis menyatakan bahwa pertunjukan teatrikal memiliki peralatan transmisi yang tidak dimiliki media lain untuk berkomunikasi.
Peralatan transmisi tersebut adalah elemen-elemen pertunjukan teatikal yang terdiri dari laku para pelaku, penulisan naskah drama, penyutradaraan, penataan artistik dan audio visual, pengelolaan produksi, dan penataan ruang riil dan ruang imajiner panggung pertunjukan (Pavis : 128129).

Pemindahan pesan budaya menjadikan pertunjukan teater menjadi intertekstual. Pemindahan budaya terjadi, yaitu antara budaya sumber (produser, pengirim) ke budaya target (penanggap, penonton) melalui mise en scène. Pertunjukan budaya sumber, tradisi lisan misalnya, berarti menuliskan rangkaian konkretisasi dari transformasi elemen-elemen pertunjukan teater kepada penontonnya. Pavis menyatakan bahwa keadaan tersebut dilakukan dengan membentuk mise en scène pertunjukan dan merekonstruksi langkah-langkah penciptaan artistik secara metodis, sistematis, dan teknis.

Teori yang disebut Pavis (1992: 24-29) dengan teori mise en scène didefinisikan sebagai sistem penandaan yang hadir secara bersamaan atau berlawanan dalam ruang dan waktu tertentu di hadapan penonton. Mise en scène merupakan suatu entitas struktural, yaitu suatu objek teoretis atau objek pengetahuan yang mengganti keberadaan seorang sutradara dan seniman pencipta lainnya. Dalam wilayah kajian mise en scène perlu dibedakan antara teks drama dan teks pertunjukan. Teks drama merupakan naskah verbal yang dibaca dan didengar dalam pertunjukan. Teks ini merupakan teks yang ditulis sebelum pengarang drama pertunjukan hadir dan bukan teks yang ditulis dan hadir sesudah pelatihan improvisasi atau pertunjukan. Teks pertunjukan merupakan semua apa yang dicipta secara audio visual di atas panggung, tetapi belum dianggap sebagai suatu sistem makna, atau belum disebut sebagai suatu wilayah keterhubungan sistem penandaan pertunjukan sebelum mendapat tanggapan dari penonton.

Kehadiran mise en scène sebagai suatu sistem dikarenakan penerimaan dan rekonstruksi oleh penonton berkat proses penanggapannya. Membaca mise en scène merupakan cara menginterpretasi sistem struktur yang diproduksi oleh artistik pertunjukan teatrikal. Tujuannya bukan untuk melakukan rekonstruksi kehendak seniman, tetapi membantu penonton memahami sistem artistik yang diproduksi oleh seniman pencipta. 
Pavis mengatakan bahwa teori mise en scène menunjukkan bagaimana penciptaan makna pertunjukan teatrikal membayangkan suatu peradaban, yaitu suatu bentuk keterhubungan antarmakna yang terjadi pada saat berbagai sistem tanda saling terkait. Namun demikian, pada saat akan menanggapai mise en scène, penanggap sering terjebak dalam menganalisis peran dan fungsinya secara normatif terutama ketika sedang membangun makna.

\section{Tahapan Mise En Scène Pertunjukan Teater Kalamanungsa}

Pertemuan budaya sumber dan budaya target dalam proses penciptaan pertunjukan teater Kalamanungsa melalui pembentukan mise en scène pertunjukan dalam tahapan sebagai berikut.

Tahap pertama (T0), yaitu identifikasi dan pelacakan ide dari tradisi lisan dalam hal ini mitos Betara Kala. Gagasan-gagasan masih abstrak belum memiliki wujud yang jelas, dan berada dalam pemikiran. Tahapan ini digunakan sebagai metode awal untuk mengenali sosok Betara Kala sebagai teks dan mitos-mitos yang muncul seperti mitos ulur-ulur, ruwatan, yang hidup di masa lampau dan berkembang di masyarakat sekarang. Pada tahap ini dilakukan pencatatan-pencatatan tentang berbagai hal yang terkait dengan Betara Kala.

Tahap kedua (T1), yaitu konkretisasi tekstual, usaha mengkonkretkan gagasan melalui wujud artistik. Cara yang dilakukan adalah mencari semangat dan nilai-nilai budaya sumber. Dalam kaitannya dengan pertunjukan Kalamanungsa beberapa kisah yang berkaitan dengan Betara Kala seperti lakon Murwakala, Sudamala dicoba untuk diapresiasi dan dimaknai, baik yang bersumber dari buku teks maupun bahan audio visual. Disamping itu juga dilakukan wawancara dan diskusi dengan sesepuh, seniman dan budayawan Jawa tentang Betara Kala dan segala sesuatu yang berkaitan. Pada tahap ini mulai dibuat treatment dan draft naskah Kalamanungsa sebagi wujud T0 dan T1.

Tahap ketiga (T2), yaitu konkretisasi dramaturgi. Tahapan ini merupakan usaha penyesuaian hasil eksplorasi dengan perspektif pencipta. Di dalam proses penciptaan Kalamanungsa ini beberapa konteks budaya mulai diperhitungkan dan dipertimbangkan. Konteks budaya Jawa Timur menjadi pilihan target untuk direspon. Materi dan teknik untuk mengkonkretkan elemen-elemen pertunjukan diekplorasi dan dikreasikan. Materi yang masih berupa draft naskah dan berbagai catatan lainnya ditulis dalam bentuk draft floor plan dan dilakukan proses ujicoba dalam bentuk potongan-potongan adegan. Pada tahap ini paling tidak akan diperolah gambaran-gambaran spektakel pemanggungan yang nantinya akan dipilih dan menjadi dasar proses penggarapan/ proses konkretisasi pemanggungan. Pada tahapan ini draft naskah dan floor plan masih terus dikembangkan hingga memperoleh hasil yang maksimal yang sesuai dengan hasil eksplorasi awal dan perspektif pencipta.

Tahap keempat (T3), yaitu konkretisasi pemanggungan. Tahapan ini merupakan usaha konkretisasi berbagai elemen pertunjukan yang dilandasi proses tahapan T0, T1, dan T2. Konkretisasi ini merupakan terapan dari metode, sistem dan teknik latihan dan penyutradaraan yang menjadi pilihan dan karakateristik pencipta. Pada tahap ini berbagai elemen pertunjukan seperti musik, artistik, stage, lighting mulai diolah sebagai upaya untuk memperoleh spektakel pemanggungan yang sesuai dengan horison harapan pencipta.

Tahap kelima (T4), yaitu konkretisasi resepsi. Tahapan ini merupakan konkretisasi penerimaan. Dilakukan ujicoba mendekatkan konkretisasi penciptaan elemen-elemen pertunjukan kepada penerimanya atau penonton. Pada tahap awal dilakukangeneralrehersialdengan jumlah penonton terbatas sebelum dilaksanakan pertunjukan atau pemanggungan utamanya.

\section{Penyutradaraan}

Pertunjukan teater Kalamanungsa ini diolah dengan mengadopsi penyutradaraan model Llyod Anton Frerer. Kerja sutradara model Frerer (1996: 4) adalah proses memilih dan menganalisis naskah, merancang audisi dan pilihan pemeran, membimbing latihan aktor, menyiapkan elemen pementasan, dan mengevaluasi hasil.

Model penyutradaraan Frerer tersebut dalam proses penciptaan seni pertunjukan Kalamanungsa secara teknis dikelompokkan menjadi tiga tahapan kegiatan yaitu: (a) Pra Penggarapan (b) Proses Latihan, dan (c) Penyelarasan. Secara rinci proses tersebut dijabarkan sebagai berikut. 


\section{Pra Penggarapan}

Pra penggarapan mencakup beberapa proses kegiatan yang semua mengacu pada konsep ide dan konsep pertunjukan. Ide-ide yang diperoleh dari eksplorasi baik secara langsung melalui pengamatan kehidupan maupun eksplorasi tekstual dijadikan bahan dasar untuk dikemas dengan konsep pertunjukan. Tahapan pra penggarapan ini meliputi (1) observasi tentang mitos-mitos Jawa khususnya tentang Betara Kala. (2) proses penulisan naskah. (3) observasi tentang musik digital. (4) observasi tentang musik etnik, dan (5) observasi gambar gerak, video dan animasi.

Hasil observasi berbagai hal di atas didiskusikan dengan teman-teman sejawat dan para ahli dibidang masing-masing untuk bekal proses selanjutnya. Sebelum memasuki proses latihan, dilakukan kerja studio berupa pembuatan polapola musik khususnya musik yang berkaitan dengan bunyi-bunyi digital.

Pola musik dibuat berdasarkan acuan naskah (mood/ suasana tiap-tiap adegan). Pada saat kerja studio untuk pembuatan pola musik digital dibantu oleh para aktor dengan panduan dialog masing-masing peran agar memperoleh kesesuaian dan ketepatan suasana maupun waktu. Berdasarkan pola musik digital yang sudah jadi ini dibuat slide dari hasil observasi gambar gerak/ video dan animasi yang prosesnya juga didasarkan atas adegan dalam naskah, mood/ suasana dan simbol-simbol yang sesuai dengan kebutuhan cerita.

\section{Proses Latihan}

Ada dua proses latihan yang menjadi perhatian khusus dalam penciptaan seni pertunjukan teater ini. Yang pertama adalah latihan yang berkenaan dengan penokohan-penokohan yang telah dibuat yang diwujudkan dalam bentuk teks naskah (dialog), yang kedua adalah latihan musik.

Latihan pertama (penokohan) tahapan proses latihannya adalah: (1) diskusi naskah (bedah naskah), (2) pembacaan dramatik dengan pola musik digital, (3) latihan pengadeganan dengan pola musik digital.

Latihan kedua (musik - live) tahapan proses latihannya adalah: (1) diskusi naskah dan bedah pola musik digital, (2) mempelajari dan menggarap musik perbagian adegan, (3) latihan kekompakan dan harmonisasi.
Dua proses latihan ini pada tahap awal dilakukan tidak bersama-sama karena dalam proses latihan awal masing-masing akan memerlukan ruang, waktu, dan intensitas yang berbeda kecuali diskusi naskah (bedah naskah dan bedah pola musik) dilakukan bersama-sama.

\section{Penyelarasan}

Penyelarasan dalam penciptaan seni pertunjukan teater ini adalah proses penggabungan antara latihan pertama dan kedua. Tahapan proses yang dilakukan adalah latihan peradegan dengan musik dan slide, latihan lengkap (musik, lampu, dan properti yang lain), penyelarasan dan penghalusan, dan evaluasi.

Tahapan-tahapan tersebut dilakukan agar diperoleh seni pertunjukan yang utuh satu kesatuan, mencapai efek estetik yang diharapkan.

\section{Penokohan}

Tokoh atau pelaku dalam sebuah cerita menurut Burhan Murgiyanto (2005: 165) menunjuk pada orangnya atau pelakunya. Sedangkan lakuan akan berkaitan dengan bagaimana tokoh tersebut berlaku atau berperilaku, menunjuk pada sifat sehingga bisa juga disebut watak, perwatakan, dan karakter.

Dalam pertunjukan teater Kalamanungsa ini ada tujuh tokoh sebagai pemeran yaitu: Dalang, Salewa, Kala, Penari, dan tiga orang Penembang. Dalang dalam hal ini tidak berkostum ala dalang Jawa melainkan menggunakan pakaian keseharian berupa kaos putih, celana hitam besar model celana Madura dengan asesoris kain warna merah panjang serta udeng. Kala sebagai sang waktu sang keburukan atau sisi gelap hanya ditampilkan lewat siluet dan atau suara saja. Salewa sebagai tokoh utama dengan karakter keras dan secara sosial adalah orang berhasil/kaya/elegent akan menggunakan kostum hem warna hitam dan celana putih, berdasi merah dengan rambut warna blonde/ kuning. Penembang menggunakan kostum yang diolah dari jarik ataupun asesoris warna Jawa khusunya Jawa Timur.

Tujuh tokoh yang diperankan dalam pertunjukan teater Kalamanungsa tersebut dijelaskan sebagai berikut.

\section{Salewa}

Tokoh Salewa dalam pertunjukan teater Kalamanungsa secara fisik adalah tokoh yang mengacu pada simbol-simbol modern, berpenampilan metrosek- 
sual, rambut diwarna, perlente, dan berdasi. Salewa dalam kehidupan keseharian adalah tokoh yang sebenarnya masih mempercayai tradisi, hal-hal yang berbau mitos dan kepercayaan, namun tokoh Salewa ini juga tokoh yang berkarakter selalu hatihati dengan pikiran-pikiran yang realistis. Karena kehati-hatiannya, tokoh Salewa ini terkadang menjadi lupa diri dan mudah hanyut pada situasi yang dirasa memberikan keamanan dan kenyamanan dirinya.

\section{Dalang Narator}

TokohDalangadalahsosokyangmengendalikan cerita sekaligus sebagai narator. Dipilih tokoh dalang dengan dialeg Madura merupakan simbolsimbol sosial yang ada di masyarakat Jawa Timur yang sangat kuat berpengaruh dalam kehidupan keseharian termasuk lingkungan masyarakat tradisi Malangan. Sebagian besar pemain wayang topeng adalah masyarakat yang dulunya berasal dari Madura.

\section{Dalang Sejati}

Dalang Sejati adalah tokoh yang secara fisik dihadirkan sebagai tokoh yang memberi simpulan pada akhir adegan. Tokoh ini tidak secara langsung mengendalikan cerita namun hadir sebagai simbol kekuatan dan kekuasaan yang tidak nampak yang ada di masyarakat Jawa. Bahwa masih ada sutradara di atas sutradara. Masih ada kekuatan yang lebih dari kekuatan yang dimiliki manusia.

\section{Kala}

Tokoh Kala dalam pertunjukan Kalamanungsa ini sebagai sang keburukan atau sisi gelap dan sang kebaikan atau sisi baik Salewa. Dengan kata lain tokoh Kala adalah kembaran Salewa yang dalam kepercayaan orang Jawa adalah dulur/ari-ari. Tokoh Kala hanya ditampilkan lewat siluet dan atau suara saja. Tokoh Kala muncul dalam pikiranpikiran Salewa baik sengaja dimunculkan oleh Salewa sendiri maupun muncul secara situasional pada saat kondisi Salewa dalam ketidaksadaran.

\section{Penari}

Tokoh penari yang ditampilkan adalah tokoh imajiner yang dibayangkan dan yang dipikirkan olah Salewa. Tokoh penari ini dimunculkan juga sebagai gambaran masa lalu Salewa. Masa lalu Salewa lahir dari hawa nafsu semata, dari hubungan yang muncul begitu saja karena alasan-alasan yang situasional seperti lahirnya Betara Kala.

\section{Penembang 1}

Tokoh Penembang 1 adalah tokoh yang secara fisik ditampilkan dengan simbol-simbol ketradisiannya, dalam keseharian berpakaian ala Jawa, dengan logat dialeg Jawa, dengan perilaku yang nJawani. Tokoh Penembang 1 ini tokoh yang lugu, terkadang tanpa pikir panjang (sludarsludur). Secara sosiologis tokoh Penembang 1 ini adalah seorang penghibur atau dalam bahasa Jawa disebut wong mbarang.

\section{Penembang 2}

Tokoh Penembang 2 adalah tokoh yang hadir bersama Penembang 1, sama-sama sebagai penghibur. Secara fisik tokoh ini juga menggunakan simbol-simbol ketradisian keseharian ala Jawa, namun tokoh Penembang 2 ini adalah tokoh yang sedikit nakal, sensasional, memiliki kecenderungan sebagai playboy dan suka memanfaatkan kesempatan dalam kesempitan, terutama dalam hal penampilan dan perhatian wanita.

\section{Penembang 3}

Tokoh penembang 3 adalah sosok wanita yang menarik, memiliki gerak-gerik yang gemulai dan memiliki suara yang sangat merdu. Sebagai tokoh penghibur juga, tokoh penembang 3 ini sering menjadikan Penembang 1 dan 2 berkonflik. Konflik karena seolah-olah tokoh Penembang 3 ini tidak membagi perhatian pada kedua penembang lainnya. Sebagai seorang yang pandai merajuk tentu saja tokoh Penembang 3 ini juga mampu menciptakan situasi yang konflik menjadi netral.

\section{Elemen Pemanggungan}

Lakuan tokoh dan musik akan ditampilkan di atas panggung yang dibagi dua gradasi atas bawah. Backdroop hitam ditata melengkung ke dalam sebagai latar belakang untuk memberi aspek kedalaman ruang. Enam layar putih transparan diletakkan tiga sap didepan latar belakang hitam dengan sudut mengerucut ke tengah panggung belakang, sebagai layar untuk bermain siluet. Disamping itu layar transparan juga digunakan sebagai set dekor yang mengimajinasikan ruang, disamping difungsikan pula untuk layar slide projektor yang memuat gambar atau animasi. Dengan kata lain panggung yang dipilih untuk pertunjukan teater Kalamanungsa ini adalah panggung sugestif. Diharapkan penggunaan pang- 
gung dengan properti semacam ini akan diperoleh dimensi-dimensi ruang dan waktu.

Pemusik menjadi bagian dari lakuan aktor dan bagian dari pertunjukan. Musik dalam penciptaan teater Kalamnungsa ini akan menggunakan beberapa peralatan sehingga akan ada penataan seefektif mungkin. Pemusik dan peralatannya diletakkan di bagian apron/ depan panggung dengan ketinggian lebih rendah dari panggung utama.

Pertunjukan teater Kalamanungsa ini, musik tidak hanya digunakan sebagai ilustrasi tetapi juga sebagai pembangun suasana, sebagai pengiring gerak (tari), yang berjalan beriringan, saling mengisi dan saling menguatkan. Kedudukan musik dicoba untuk disejajarkan dengan bangunan cerita dalam pertunjukan. Musik digarap sebagai bunyibunyian yang dilekatkan dengan karakterisasi tokoh yang akan hadir dalam pertunjukan.

BunyidalamNurSahid(2004:116)dikategorikan menjadi bunyi alami, atau bunyi-bunyi alam, bunyi perangkat atau alat mesin, sperti mobil, mesin pabrik dsb, dan bunyi yang dikarenakan adanya aksi tertentu seperti meja ditendang, batu dilempar dsb. Bunyi-bunyi yang dikatagorikan seperti tersebut di atas dalam pertunjukan teater Kalamanungsa ini juga dihadirkan namun tidak secara langsung melainkan diolah dengan komputer.

Bunyi-bunyi yang diperlukan tersebut diolah dan diambil dari media komputer dengan menggunakan program Frutyloop versi 8. Bunyi yang telah diolah tersebut kemudian diedit dan disesuaikan dengan adegan-adegan yang ada dalam naskah dengan menggunakan program Adobe Audition Pro 1.5. Penyesuaian tersebut didasarkan atas perhitungan durasi dan mood tiap-tiap adegan.

Proses berikutnya musik digital olahan komputer tersebut dipadu dengan alat-alat musik lainnya seperti: gitar, bas, kendang, seruling, maracas, saron, demung, gong, dan piano untuk menghasilkan efek suara yang mendukung lakuan aktor dan spektakel pemanggungan.

Musik dalam pertunjukan teater Kalamanungsa juga dipahami sebagai lagu dan atau tembang. Musik dalam hal ini mengacu pada fungsi praktisnya, menunjuk secara spesifik pada situasi sosial masyarakat di Jawa Timur. Musik juga sebagai penanda peristiwa yang akan menjadi konteks pertunjukan teater Kalamanungsa. Dengan gaya musik Artmoschestra tersebut, musik dimainkan secara langsung dan dipadu dengan musik hasil olahan dari komputer sebagai bagian kesatuan pertunjukan.

Beberapa lagu yang diciptakan oleh kelompok musik Tani Maju, yang kebetulan sedang digemari di Malang Raya pada saat ini (pada saat proses/ pertunjukan Kalamanungsa ini) dan lagu Semanggi Suroboyo dimainkan sebagai bagian dari cerita. Lagu-lagu tersebut sengaja dipilih dan dimainkan karena sesuai dengan konteks cerita khususnya adegan para penembang pada saat ngamen/ mbarang. Di samping itu ada beberapa tembang Jawa yang dinyanyikan pula agar memperoleh suasana yang lebih kuat ketradisiannya.

Penggunaan tehnik perpaduan instrumen musik baik digital, etnik, serta instrumen konvensional atau modern lainnya diharapkan dapat mengkreasikan nada-nada mayor minor, harmonis disharmonis, pentatonis diatonis, menjadi bunyi atau musik yang sesuai dengan kebutuhan pertunjukan teater Kalamanungsa. Unsur musik etnik yang banyak memiliki kaidahkaidah yang baku dicoba lebih arif untuk diolah sebagai musik eksperimen dengan menggunakan media etnik sebagai penguat warna, progres dari eksistensi local genius sedangkan unsur digital sebagai penyampainya.

Konsep musik tersebut di atas mencerminkan penghargaan dan perhormatan pada semua unsur pembangun. Diharapkan musik ini akan sejajar dengan bangunan cerita yang akan mampu menghadirkan tokoh-tokoh yang berkarakter dalam sebuah lakuan seni pertunjukan teater Kalamanungsa

Untuk mempertemukan dunia keseharian dan dunia imajiner dalam pertunjukan Kalamanungsa akan dipergunakan juga gambar gerak atau animasi. Gambar gerak yang dimaksud dalam pertunjukan adalah siluet/efek bayangan, seperti teknik yang digunakan wayang kulit dan gambar hidup hasil dari rekaman kamera dan animasi yang telah diolah dengan progam komputer Adobe Premiere dan Adobe Ilustration yang hasilnya ditayang ulang dengan proyektor/ LCD pada saat pemanggungan.

Penggunaan gambar gerak dan animasi tersebut merupakan bagian dari spektakel pemanggungan 
dan diharapkan dapat menjadi bagian pertunjukan yang ikut berbicara dalam jalinan cerita yang telah dibuat.

\section{Alur Cerita Kalamanungsa}

Kalamanungsa pada intinya bercerita tentang seseorang yang bernama Salewa. Seorang tokoh yang secara psikologis mengalami kegelisahan ketakutan karena keakuan cara berpikir dalam dirinya. Salewa selalu mempertahankan diri agar berada dalam rasa aman dan tentram. Salewa membangun eksistensi dirinya dari seorang yang lahir atas dasar kesucian. Suci sejak kecil, suci karena kodratnya sebagai manusia.

Dalam perjalanan kehidupannya, kebutuhan rasa aman dan kebahagiaan Salewa menjadikan dirinya berhati-hati dan menaruh rasa curiga terhadap orang-orang di sekitarnya yang menganggap dirinya tidak bahagia. Bahagia bagi Salewa adalah hartanya, perempuan-perempuan yang dimilikinya dan tidak akan diberikan kepada orang lain yang justru dianggap akan merugikan dirinya. Ketika tokoh Penembang atau pengamen yang menawarkan hiburan kepada Salewa justru dituduh akan mengambil harta hasil dari jerih payahnya yang telah disimpan dan dimiliki sejak lama.

Salewa dalam pertunjukan teater Kalamanungsa sebenarnya adalah tokoh yang mempunyai perangai mudah terhanyut, berfikir rasional tetapi perilakunya sering tidak rasional, serta takut akan bayangan kehilangan harta. Harta bagi Salewa adalah ukuran kebahagiaan. Salewa selalu merasa kuatir kehilangan hartanya. Ketidakyakinan, kegamangan dan ketakutan tersebut justru menjadikan Salewa berada dalam alam fikiran dan angan-angan, pengandaian dan imajinasi yang sangat tinggi. Bahkan Salewa berfikir tentang kelahirannya yang penuh dengan tipuan.

Salewa merasa tertipu dengan jati dirinya yang seolah-olah lahir dari yang suci dari sebuah hubungan lelaki dan perempuan sewajarnya. Keegoisan pikiran yang mengembara kemanamana menjadikan Salewa merasa terintimidasi dengan pikirannya sendiri. Salewa dilahirkan akibat kekhilafan, akibat dari hubungan yang tidak wajar. Karena sering terhanyut dengan alam pikiran sendiri, menjadikan Salewa seolaholah tidak berbahagia atau tampak seperti orang yang perlu mendapat hiburan atau kebahagiaan.
Ketidakadilan sikap Salewa terhadap orang disekitarnya bukanlah kejahatan, tetapi karena ketakutan dan ketidakberdayaannya terhadap pikiran-pikiran dan kesendiriannya dalam mengarungi hidup.

Kegelisahan Salewa adalah problematika masyarakat modern yang selalu berpikir bahwa manusia layak mengolah habis suratan takdirnya serta mengubah nasibnya untuk memperoleh kehidupan yang lebih baik. Salewa dan mungkin manusia pada umumnya akan tergambarkan segala kegamangan dan kegelisahan dirinya yang terpancarkan dari tabiat, perlakuan diri, karakteristik dan kecenderungan perilaku dari krisis eksistensi yang dialaminya.

'Life is not easy' hidup ini tidak mudah, seperti ungkapan Freud sangat melekat pada Salewa. Salewa berdiri di tengah-tengah kekuatankekuatan dasyat antara realitas hidup dan imajinasi harapan. Kekuatan-kekuatan yang menciptakan konflik dan penguasaan menjadikan ego Salewa merasa terancam.

Tokoh Salewa adalah pesan-pesan budaya yang terinspirasi dari sosok Betara Kala. Betara Kala merupakan, Sokoh yang diciptakan dalam pewayangan sebagai simbol kerusakan. Simbol keserakahan yang akan menghabisi dunia dan isinya. Dengan kaca mata positif, pandangan terhadap tokoh Betara Kala menunjukkan bahwa apa yang terjadi di bumi ini memiliki hukum sebab akibat.

Salewa dengan kompleksitas perilakunya juga produk dari segala sesuatu yang melintas pada dirinya, baik internal maupun eksternal. Jika Betara Kala adalah produk dari kelalaian atau kelengahan maka Salewa adalah Betara Kala dalam wujud manusia jaman sekarang sebagai titisan atau paling tidak memiliki perjalanan kelahiran yang sama, sama-sama lahir dari sebuah kesalahan atau kekhilafaan.

Betara Kala lahir dari Betari Uma ketika melanglang buana di atas samodra pada saat sandyakala (senjakala) bersama Batara Guru. Tanpa sengaja/ busana Betari Uma tersingkap sehingga menimbulkan gairah Betara Guru. Tanpa sengaja pula mani atau komo Betara Guru keluar dan menjadi makhluk yang tak jelas jatidirinya, yaitu Betara Kala. Makhluk yang tak jelas jatidirinya ini pada akhirnya mengetahui bahwa orang tuanya adalah Betara Guru. 
SementaraSalewalahirkarenaadanyahubungan lelaki dan perempuan yang pada dasarnya bukan pasangan hidupnya, bukan hubungan yang benar melalui pernikahan yang sah. Salewa lahir karena nafsu, dengan alasan profesionalisme kerja yang disalahgunakan untuk memperoleh kebebasan yang sebenar-benarnya bebas.

Sebagai dewa yang bijaksana dan bertanggung jawab, Betara Guru mengakui bahwa Betara Kala tersebut adalah anaknya meski dari hubungan yang tidak semestinya. Sudah sepantasnya seorang anak minta nama, minta pakaian, dan minta makan pada orang tuanya. Betara Guru pada awalnya memberi nama jajar ala, namun atas pertimbangan Betara Narada dilengkapi namanya menjadi Betara Kala.

Jika Betara Kala diberi sandang, pangan, dan papan oleh Betara Guru yang sudah mengakui sebagai bapaknya, lalu Salewa sebagai sosok manusia masa kini siapa yang akan memberi makan, siapa yang memberi pakaian, dan siapa yang akan memberi papan.

Pemahaman wurung atau salah dalam konteks mani atau komo Betara Guru dalam istilah pewayangan disebut sebagai komo wurung alias komo salah dapat diartikan bahwa manusia yang direpresentasikan lewat tokoh Salewa sebenarnya tidak bisa berperilaku semena-mena yang tak jelas ujung pangkalnya. Termasuk ketika Betara Guru justru menyalahkan Betara Uma karena membiarkan kainnya tersingkap dan Betara Guru merasa tidak bersalah atau dengan kata lain tidak mau disalahkan sehingga menyalahkan orang lain (Betara Uma) untuk menutupi kesalahannya adalah perilaku yang juga tidak sepatutnya dilakukan oleh manusia.

Dalam pertunjukan teater Kalamanungsa, persoalan-persoalan seperti ini dihadirkan agar menjadi introspeksi atau kontemplasi bagi para penikmat atau penonton. Pertunjukan teater Kalamanungsa adalah potret prilaku kehidupan manusia modern atau zaman sekarang.

\section{Perspektif dan Konteks Budaya Kala- manungsa}

Pertunjukan teater Kalamanungsa melalaui tahapan proses kreatif konkretisasi dramaturgi. Tahapan ini merupakan usaha penyesuaian hasil eksplorasi dengan perspektif pencipta. Dalam proses penciptaan Kalamanungsa beberapa konteks budaya diperhitungkan dan dipertimbangkan. Konteks budaya Jawa Timur khususnya ludruk dan wayang topeng Malangan menjadi pilihan target budaya untuk direspon. Materi dan teknik untuk mengkonkretkan elemen-elemen pertunjukan diekplorasi dan dikreasikan.

Dengan berbekal perspektif pencipta dan konteks budaya Jawa Timur, materi yang masih diwujudkan dalam bentuk draft naskah dan berbagai catatan lainnya diproses dan diujicoba dalam bentuk potongan-potongan adegan. Pada tahap ini paling tidak akan diperolah gambarangambaran awal spektakel pemanggungan yang nantinya akan dipilih dan menjadi dasar proses penggarapan/ proses konkretisasi pemanggungan. Pada tahapan ini draft naskah dan floor plan masih terus dikembangkan hingga memperoleh hasil yang maksimal yang sesuai dengan hasil eksplorasi awal dan perspektif pencipta.

\section{Resepsi Penonton Kalamanungsa}

Teks naskah Kalamanungsa ditulis sebelum pertunjukan, hadir pada saat pelatihan atau improvisasi sebelum pertunjukan. Sedangkan teks pertunjukan hadir pada saat pertunjukan secara audio visual di atas panggung. Teks-teks tersebut belum dianggap sebagai suatu sistem makna, atau belum disebut memiliki wilayah keterhubungan sistem penandaan pertunjukan sebelum mendapat tanggapan atau direspon penonton atau penikmat maka pertunjukan teater Kalamanungsa perlu dikonkretisasi resepsi.

Dalam kerangka konkretisasi resepsi, dilakukan ujicoba untuk mendekatkan elemen-elemen penciptaan pertunjukan kepada penerima atau penonton. Pada tahap awal dilakukan general rehersal dengan jumlah penonton terbatas sebelum dilaksanakan pertunjukan atau pemanggungan utama.

General rehersal yang dilakukan dibuat seolaholah sebagai pertunjukan yang sebenarnya. Target yang ingin dicapai adalah memperoleh respon penonton pada saat dan setelah Kalamanungsa ditampilkan. Untuk mendapatkan respon yang lebih dalam, maka pada saat akhir pertunjukan dilakukan diskusi atau sarasehan. 


\section{Tingkat Kesulitan Penggarapan}

Terlepas dariberbagai pendapat, kritikdan saran penikmat, serta kendala-kendala yang muncul, pada dasarnya pertunjukan teater Kalamanungsa mencoba untuk menemukan satu kebaruan pertujukan teater. Mencoba mengakomodir berbagai aspek pertunjukan baik seni sastra, seni teater, seni musik, seni tari, seni rupa, dan seni videografi dalam satu kesatuan pertunjukan. Disamping itu pertunjukan teater Kalamanungsa ini juga mencoba merespon munculnya teknologiteknologi digital seperti penggunaan komputer, LCD, dan sound system.

Karena mengakomodir berbagai macam aspek pertunjukan seperti tersebut di atas, maka tingkat kesulitan proses penggarapannya menjadi lebih tinggi. Beberapa kendala atau kesulitan yang muncul antara lain: (1) Pola musik yang dibuat dari komputer dalam penggarapannya tetap memerlukan warna suara para aktor, khususnya yang terkait dengan lagu yang dinyanyikan. (2) Proses latihan yang dimulai dari proses membuat pola musik di studio belum terbiasa dalam proses penggarapan teater, sehingga perlu waktu untuk beradaptasi. (3) Memadukan durasi dialog tiaptiap adegan dengan durasi pola musik komputer cukup memerlukan waktu dan ketelitian. (4) Pemilihan unsur bunyi pola musik komputer perlu ketelitian dengan kesesuaian suasana tiap-tiap adegan. (5) Latihan adegan dengan mengikuti pola musik memerlukan aktor yang memiliki ketajaman musik, dan (5) Penggabungan pola musik komputer dengan musik langsung memerlukan waktu dan ketajaman pemain musik, terlebih musik langsung terdiri dari alat musik tradisional dan modern.

Berbagai kesulitan tersebut di atas merupakan tantangan dalam penciptaan pertunjukan teater Kalamanungsa yang kesemuanya harus dilewati dengan arif dan bijaksana.

\section{Penutup}

Nilai-nilai tradisi atau mitologi banyak berpengaruh terhadap penulisan karya sastra dan penciptaan karya seni teater Indonesia. Ketika tradisi lisan menjadi sumber, maka identitas cerita lisan atau tradisi lisan tidak lagi berbicara hanya di sekitar pemiliknya, tetapi juga bersinggungan dengan nilai-nilai budaya dari penikmatnya yang lain. Kalamanungsa adalah salah satu bentuk karya seni teater yang bersumber dari tradisi lisan tersebut.

Tradisi sering diterjemahkan sebagai pewarisan, norma-norma, dan adat-istiadat yang perlu dipertahankan. Sikap demikian sering dipertentangkan dengan pengertian modern atau perubahan. Bagi yang tunduk pada nilainilai dan konsep tradisi, mereka menganggap tradisi sebagai sesuatu yang agung dan klasik serta memiliki aspek-aspek spiritual yang tidak boleh disentuh karena dianggap sebagai sesuatu yang keramat atau sakral. Kalamanungsa sebagai sebuah karya pertunjukan teater yang bersumber dari tradisi bukanlah karya pertunjukan yang mempertentangkan tradisi dengan modern. Kalamanungsa adalah sebuah karya yang mencoba merepresentasi tradisi dengan bahasa yang baru.

Dasawarsa sekarang, saat dunia sedang terbawa arus globalisasi dan teknologi modern, dunia rekaan dan imajinasi yang dikhawatirkan tergusur oleh berbagai ilmu eksakta atau ilmu pasti ternyata masih berkembang dengan pesat. Secara khusus gejolak globalisasi dan teknologi tidaklah mengendurkan semangat berteater. Teater tetap dibuat dan diciptakan. Perkembangan teknologi modern, seperti: komputer, musik digital, proyektor/ LCD dan sebagainya justru membantu tumbuh kembangnya penciptaan teater maupun minat masyarakat untuk berteater.

Kalamanungsa sebagai sebuah karya pertunjukan teater yang bersumber dari tradisi juga merespon gejolak globalisasi dan teknologi tersebut dengan memanfaatkan berbagai teknologi modern sebagai bahasa ungkapnya. Penggunaan teknologi tersebut merupakan bagian dari usaha untuk mencari idiom dan bahasa ekspresi pertunjukan yang baru dan segar. Sebagai cara berekspresi baru, dengan bahasa yang baru untuk mengutarakan sebuah kebenaran yang terus tumbuh, untuk mengucapkan kenyataan-kenyataan yang terusmenerus berkembang.

Kalamanungsa tidak hanya sebagai sebuah karya pertunjukan teater yang mencoba membangun nilai-nilai yang sudah kedaluwarsa, tetapi juga membalik menjadi sebuah akulturasi dan pembebasan diri dari kemacatan tata nilai yang ternyata sudah bergeser. Tontonan yang diciptakan dan dilakukan merupakan sebuah pertunjukan yang mencerminkan pembebasan. 
Perbedaan tata nilai yang tidak sesederhana hitam putih, kiri dan kanan, buruk lawan baik, atau tradisi lawan kontemporer saja, tetapi merupakan kehadiran nuansa yang memerlukan cara berpikir baru untuk memahaminya. Nilai-nilai bertumbukan, tumpang-tindih, membingungkan, dalam susunan harmoni baru.

Padadasarnyapertunjukan teater Kalamanungsa merupakan usaha kreatif dalam pencarian-pencarian idiom dan bahasa pengucapan yang baru. Pertunjukan yang memanfaatkan semua konvensi pertunjukan yang sudah diterima oleh masyarakat, namun diberi nuansa yang baru atau lain sama sekali.

Sebagai sebuah respon terhadap pergerakan tatanan kehidupan manusia yang menciptakan perubahan-perubahan menuju masyarakat modern, pertunjukan teater Kalamanungsa ini disarankan untuk dapat dimanfaatkan dan dijadikan sebagai dasar atau pola yang perlu dikembangkan untuk menemukan satu kebaruan dari pertunjukan teater.

Pertunjukan teater Kalamanungsa yang mencoba merespon munculnya teknologi digital seperti penggunaan komputer, LCD, dan sound system, yang mengakomodir berbagai aspek pertunjukan baik seni sastra, seni teater, seni musik, seni tari, seni rupa, dan seni videografi dalam satu kesatuan pertunjukan memiliki tingkat kesulitan proses penggarapan.

Berbagai kendala dan kesulitan yang terjadi dalam pertunjukan teater Kalamanungsa ini diharapkan dapat dipergunakan sebagai bahan acuan untuk proses-proses penggarapan berikutnya. Dengan kata lain bahwa pertunjukan teater memerlukan persiapan-persiapan pelaku seni pertunjukan yang: 1 . memahami musik baik yang diolah dari komputer maupun yang dimainkan secara langsung, 2. memiliki ketrampilan bernyanyi atau memahami bunyi maupun musik sebagai instrumen atau lagu, 3. memulai proses penggarapan dari berbagai sudut pandang agar terbiasa dan memiliki kecepatan dan ketepatan beradaptasi.

Respon terhadap globalisasi dalam konteks penguatan lokal genius, kearifan dalam berkarya dan berkesenian disarankan untuk diekspresikan melalui pertunjukan teater dengan menggunakan indera atau pencitraan yang terbangun dari unsur seni budaya baik tradisional maupun modern.
Pertunjukan teater yang merepresentasi tradisi dengan bahasa yang baru, yang memanfaatkan berbagai teknologi modern sebagai bahasa ungkap, yang menggunakan teknologi sebagai bagian dari usaha untuk mencari idiom dan bahasa ekspresi pertunjukan yang baru, yang segar, memerlukan satu pengkondisian awal, baik pelaku seni maupun penonton atau penikmatnya. Hal ini dikarenakan sebagai cara ekspresi baru, penggunaan bahasa yang baru untuk mengutarakan sebuah kebenaran yang terus tumbuh dan berkembang tidak dengan mudah dapat dipahami.

Pendidikan dan pembelajaran terhadap nilainilai budaya disarankan secara khusus diwujudkan dengan tanda dan simbol-simbol kehidupan sebagai suatu proses penyampaian informasi, gagasan, emosi, dan keahlian, atau ekspresi komunikasi dalam bentuk model pembelajaran seni pertunjukan teater.

\section{Kepustakaan}

Frerer, Llyod Anton. 1996. Directing for the Stage. Illinois: NTC Publishing Group.

Comte, 1990, dalam K.J. Veegar (ed). Realitas Sosial (refleksi filsafat sosial atas hubungan individumasyarakat dalam cakrawala sosiologi. Jakarta: PT Gramadia Pustaka Utama.

Clarence. Bernhart, 1957. The American College Dictionary. New York: Harper \& Brothers Publisher.

Hasan, Fuad. 1993. Pegindonesiaan Wayang. Kemungkinan dan Keterbatasannya. Dalam Hetermonia. Bandung: Pustaka Jaya.

Jatman, Darmanto, 2006. Seni Pertunjukan Jawa Menghadapi Masa Depan - nut jaman kelakone! Makalah Workshop dan Festival Tradisi Lisan oleh Balai

Kajian Sejarah dan Nilai Tradisional Yogyakarta, 6 - 7 September 2006.

Murgiyanto, Burhan. 2005.Teori Pengkajian Fiksi. Yogyakarta: Gajah Mada Press.

Mulyono, Sri. 1989. Wayang, Asal-usul, Filsafat, dan Masa Depannya. Jakarta: CV Haji Masagung.

Pavis, Patrice. 1992. Theatre at the Crossroads of Culture, terj. Loren Kueger. London: Routledge.

Sachari, Agus. 2002. Estetika. Makna, Simbol dan Daya. Bandung: Penerbit ITB

Sahid, Nur. 2004. "Semiotika Teater". (Laporan Penelitian), Yogyakarta: Lembaga Penelitian ISI Jogjakarta. 
Sarumpaet, Ratna. 2004 Panggung Megah Miskin Makna dalam Mitra (Jurnal Budaya dan Filsafat) Edisi 11.

Soedarso Sp. 2006. Trilogi Seni, Penciptaan Eksistensi dan Kegunaan Seni. Yogyakarta: BP ISI Yogyakarta.

Suhartono, Suparlan. 2005. Sejarah Pemikiran Filsafat Modern. Yogyakarta: Ar-ruzz.

Tofler, Alvin. 1970. dalam Milton C. Albrecht. The Sociology of Art and Literature. New York dan Washington.

Weiner, Myron. 1994. Modernisasi Dinamika Pertumbuhan. Yogyakarta: Gadjah Mada University Press.
Yudiaryani. 2002, Panggung Teater Dunia. Perkembangan dan Perubahan Konvensi. Yogyakarta: Pustaka Gondosuli.

Saini KM. 2000, "Teater Indonesia Sebuah Perjalanan dalam Multikulturalisme" dalam Nur Sahid (ed) Interkulturalisme (dalam) Teater. Yogyakarta: Yayasan Untuk Indonesia.

Kompas Cybermedia. 31 Agustus 2007, (hhtp:/www. kompas.com)

Mitter, Shomit. 2002. Stanilavski, Brecht, Grotowski, Brook. Sistem Pelatihan Lakon. Terj. Yudiaryani. Yogyakarta: MSPI dan ARTI. 